\title{
Students Learning Orientations and Adult Work (SLOG): a case in collaborative cross-national educational research
}

\author{
Angela Little (on behalf of the Students Learning Orientations Group)
}

\section{Students Learning Orientations and Adult Work: an international study}

The research described briefly in this article focuses on the different types of learning orientation which students develop during their school careers and on the implications which these have for long term motivation at work. This account describes mainly the research rationale, organisation and method. Further details of research method and current research findings are described elsewhere [SLOG 1984]. The research is being carried out by a collaborative research network known as the Students Learning Orientations Group. Our acronym is SLOG ${ }^{1}$ which describes not only the research group but also the student activity which we research and - to some extent - the research activity itself!

\section{The Research Problem and History}

Societies everywhere are becoming highly bureaucratised and are making increasing use of educational qualifications for the recruitment, selection and promotion of personnel in wage and salaried employment. The jobs for which the highest qualifications are sought are those which offer the highest level of income, security and status. The value attached to qualifications and to the examinations and assessments leading to them is consequently very great. Scoring good grades in an examination or assignment becomes a major goal or motive for classroom learning. The selection function relegates other functions of the educational institution to the background. Educational institutions become places where people prepare to take examinations and be assessed rather than places of learning. This domination of assessment over learning is considered to be inimical to the long term growth and development of individuals and of society since it encourages the production of highly 'ritualistic' workers - highly desirable perhaps for routine tasks but not for jobs requiring initiative, innovation, creativity and entrepreneurial drive.

This general thesis, known as 'The Diploma Disease', was developed during the seventies by Dore and colleagues at the Institute of Development Studies [Dore 1976; Little and Dore 1982; Oxenham 1984]. A simple model of the thesis is presented below.

\begin{tabular}{|c|c|c|c|}
\hline $\begin{array}{l}\text { Labour market } \\
\text { structure and } \\
\text { use of certificates } \\
\text { for job } \\
\text { allocation }\end{array}$ & $\begin{array}{c}\text { Intense } \\
\text { demand for } \\
\text { schooling } \\
\text { and } \\
\text { certificates }\end{array}$ & $\begin{array}{l}\text { Assessment } \\
\text { Orientation } \\
\text { in } \\
\text { educational } \\
\text { institutions }\end{array}$ & $\begin{array}{l}\text { Negative long } \\
\text { term effects } \\
\text { on } \\
\text { individuals } \\
\text { and society }\end{array}$ \\
\hline
\end{tabular}

1 SLOG is an acronym for the Students Learning Orientations Group. Members of this collaborative research group, from India. Japan. Malaysia. Nigeria. Sri Lanka and the United Kingdom. include J. Indiresan, R. Ghatak (India): H. Azuma. K. Kashiwagi. H. Ono (Japan): T. Marimuthu. H. Mukerjee. J. Sarjit Singh. J. A. Phillips (Malaysia); S. Niles. B. Gaba (Nigeria): A. de Silva. C. Gunawardene, Rupasinghe, Sandarasegaram (Sri Lankil): A. W. Little (coordinator - United Kingdom).
The starting point of the earlier research was the labour market and the use of educational qualifications for recruitment, selection and promotion in work organisations. The next stage in the research examined the intensity of demand for schooling and certificates and its impact on teaching and learning activity in schools.

IDS Bullerim. 1984. vol I5 to 4. Institule of Development Studies. Sussex 
The SLOG research seeks to examine the link between the final two boxes in the model presented above - between measures of assessment orientation and long term work orientations and behaviour. This link is currently being examined in six countries - India, Japan, Malaysia, Nigeria, Sri Lanka and England. The confirmation of the link between learning orientation in school and work orientation and behaviour is crucial to the Diploma Disease thesis.

The purpose of the international study is twofold. First, there is sufficient mounting concern about the ill effects of examinations in all countries for it to be considered a 'common problem'. Collaboration between countries and researchers working on a common problem is mutually beneficial. Second, examining relationships between school characteristics and work characteristics in a variety of different cultural and economic settings enables one to separate out the effects of school from the effects of culture, economy, etc. By randomising other relevant variables one can separate the real from the spurious relationship between school and work.

\section{Collaborative Research Organisation \\ Research institutions}

From the outset of this research in 1980, researchers from five countries - India, Japan, Malaysia, Sri Lanka and the United Kingdom - have been involved in the development of hypotheses, research design and research tools. The institutions currently involved are the Indian Institute of Technology, Madras; Tokyo University; Tokyo Christian Womens University; University of Malaya; University of Colombo; and the Institute of Development Studies, UK. In 1982, Nigeria joined the group and was represented by researchers from the Bayero University, Kano. The research is coordinated from the Institute of Development Studies, UK. Members brought to the research group previous experience and interest in aspects of the research problem [Indiresan 1978; Indiresan and Ghatak 1983; Marimuthu 1983; Sarjit Singh and Mukerjee 1983; Niles 1981; Little 1983, 1984, forthcoming].

\section{Annual research workshop}

An indispensable feature of the research organisation is an annual research workshop, hosted by the institution of one of the group members. The first workshop in 1980 was hosted by the Marga Institute, Colombo; the second by the University of Malaya; the third by the Institute of Development Studies, Sussex, UK; the fourth by the Indian Institute of Technology, Madras, India. The function of these intensive weeklong workshops is to review the previous year's work and to develop detailed work plans for the following year. Items on the workshop agenda are wide ranging and include feedback of results, to theory-to funding, to the rights and obligations of group members, to forms of authorship for collective work, to the creation of items for pilot questionnaires and the structure of interview schedules.

\section{Funding and Organisation of Country Case Studies}

The funding and administration of individual country fieldwork is decentralised. Researchers joining the research group did so knowing that international funding for such a large scale project was unlikely and that funds would have to be sought locally. From time to time the coordinator has been able to assist in seeking funds for the Third World countries - but by and large funding has been obtained by individual country research groups. Funding for the country case studies has been generously afforded by the research institutions themselves, by the Norweigian aid organisation (NORAD), by the Leverhulme Foundation UK, and by the Ministry of Education, Japan. A current major problem is securing funds to cover the international communication elements, ie costs of the coordination, air fares for workshops and international data processing costs.

\section{Research Method}

The main characteristics of the research method are:

- longitudinal design. Profiles of student learning orientation will form the baseline data. Large samples of students will be followed through education into work (or unemployment);

- development of new measures of both learning orientation and work orientation. This is a very time consuming procedure involving a combination of small qualitative interview studies and larger questionnaire surveys;

- an emphasis on country-specific measures. We are struck by the dominant practice in 'cross-cultural' research of the 'local adaptation' of measures developed initially in Britain and America. Local adaptation usually amounts to application of a measure to a trial sample either in English or in a local language, and minor modifications of stimuli of items to ensure translation of meaning. But it is rare for the items of measures to be changed radically or for the basic factor structure of scales to be challenged (at an early stage). Even rarer is it for a measure to be developed in more than one cultural setting simultaneously. We are attempting to do just this - to develop measures of learning orientation in no less than six cultural settings.

This is an ambitious longitudinal project in six countries. After final development of the measures of 
learning orientations we would welcome other researchers to join our vent ure, on condition that they are prepared to construct and reconstruct items and scales relevant to their own country samples. Our end product is unlikely to be a simple 20 item questionnaire applicable to the entire world!

\section{Bibliography}

Boakye, J. K. A. and J. C. P. Oxenham, 1982, 'The quality of education in Ghanaian middle schools', Research Report, Institute of Development Studies, Sussex

Brooke, N. P., 1980, 'The quality of education in rural Ghana and Mexico', IDS Bulletin, vol 11 no 2, pp42-47

-and J. C. P. Oxenham, and A. W. Little, 1978, 'Qualifications and employment in Mexico', Research Report, Institute of Development Studies, Sussex

-and J. C. P. Oxenham, 1981, 'The quality of education in rural Mexican primary schools', Research Report, Institute of Development Studies, Sussex

Deraniyagala. C., R. P. Dore, and A. W. Little, 1978, 'Qualifications and employment in Sri Lanka', Research Report, Institute of Development Studies, Sussex

Dore, R. P., 1976. The Diploma Disease, George Allen and Unwin, London

1LO/JASPA, 1982, The Paper Qualification Sindrome and the Unemployment of School Leavers, Addis Ababa

Indiresan, J., 1978, 'Examinee: the neglected factor in the examination system', Higher Education, vol 4 no 2, pp268-71

-and R. Ghatak, 1983, 'Society and the educational system in India, International Review of Applied Psychology', vol 32 no 4, October
Lewin, K. M., 1980, 'Curriculum renewal and examination reform: a case study from Malaysia, IDS Bulletin, vol 11 no 2, pp34-41

Little, A. W., 1983, 'Employers and qualifications: learning from developing countries', International Review' of Applied Psychology', vol 32 no 4, pp327-46

-1984, 'Combating the Diploma Disease' in J. C. P. Oxenham (ed) op cit

-forthcoming. "The child's understanding of the causes of academic success and failure: a study of British schoolchildren', British Jownal of Educational Psychology

-and R. P. Dore, 1982, the film/video, The Diploma Disease; also 'A resource booklet for the film The Diploma Disease', Miscussion Paper no 179, IDS, Sussex

Marimuthu, T., 1983, 'Education and occupation in Peninsular Malaysia', International Review of Applied Psycho$\log y$, vol 32 no 4 , October

Niles, S., 1981, 'Dimensionality in Rotters l-E scale in Sri Lanka', Journal of Cross-Cultural Psychology, vol 12 no 4 . pp473-79

Oxenham, J. C. P., 1980, 'Employers and qualifications', IDS Bulletin, vol 11 no 2, pp6-12

-1984 (ed), Education v's. Qualification, George Allen and Unwin, London

Sarjit Singh, J. and H. Mukherjee, 1983, "The manifestations of the Diploma Disease in Malaysia secondary schools' in Fikiran-Fikiran Mengenai Pendidikan di Malaysia, Fakulti Pendidikan, Universiti Malaya

SLOG, 1984, "Assessment-oriented learning and adult work - an international study, Bulletin of the European Centre for Higher Education, no l

Unger, J., 1980, 'Severing the links between education and careers: the sobering experience of China's urban schools, 1968-76, IDS Bulletin, vol 11 no 2, pp49-54 